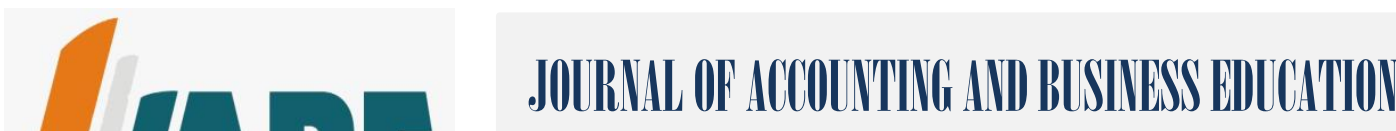 \\ P-ISSI 2528-728I B-ISSI 2028-729X

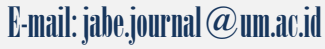

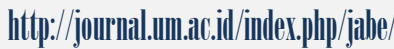

\section{The Process of Performance Based Budgeting in Probolinggo City by Utilizing SIMRAL: A Phenomenology Study}

\author{
Muhammad Avicinna Dipayana \\ Iwan Triyuwono \\ Wuryan Andayani \\ Universitas Brawijaya \\ muhavicinnad@gmail.com
}

\begin{abstract}
This study aims to interpret the performance-based budgeting process by utilizing Planning, Budgeting and Reporting Information System (SIMRAL) in Probolinggo City's budget. This research is regarded as qualitative, particularly referring to phenomenological study projected to dig deep into the informants' perspectives and their meaning. The results of this study revealed that the performance-based budgeting process in Probolinggo City with SIMRAL's utilization is interpreted the disobedience of budgeting to planning; moreover, SIMRAL is regarded as a solution for such disobedience. Referring to such a notion, a conclusion can be drawn which reads "SIMRAL is the solution for the disobedience of budgeting to planning". The understanding of the meaning of performance-based budgeting with SIMRAL's utilization did not necessarrily make the Probolinggo municipal government implement the performance-based budgeting in accordance with the rules. The factors leading to such a situasion are outlined as follows: 1) discrepancies between planning and budgeting documents, 2) reporting of performance which has not run well, 3) human resources which need strengthening, 4) the lack of leadership qualities of SKPD (working units), and 5) the lack of an integrated application system
\end{abstract}

Keywords: meaning, performance-based budgeting, SIMRAL, system

\section{INTRODUCTION}

Bastian (2006) defines performance-based budgeting as a budgeting system that is oriented to the organization's output indicators and is closely related to its vision, mission, and strategic plans. The performance-based budgeting hinges on the concept of value for money and supervision of output performance. The performance-based budget approach is projected to overcome the weaknesses of the traditional budgeting system. Such shortcomings are prevalent as it generally does not provide a clear benchmark for performance measurement entailing the achievement of public service objectives and targets (Haryanto, Sahmuddin, \& Arifuddin, 2007). Moreover, failed planning is largely due to the 
absence of an effective performance-oriented budgeting. All efforts intended to improve and achieve the organization's objectives obviously require sound and sustainable performance measurement (Bastian, 2006).

Many researchers have made attempts to examine performance-based budgeting in public sectors in Indonesia. The primary results of those studies show that performance based budgeting merely runs at the level of formatting and technical changes; however, how it contributes to paradigm shifts has not displayed significant results (Rahayu, Ludigdo, \& Affandy, 2007). An investigation by Financial Education and Training Agency (BPPK) of Ministry of Finance of the Republic of Indonesia (2013) avers that the BPPK has not fully implemented the Performance-Based Budgeting. The implementation of the performancebased budgeting is reinforced by the RTI International (2009) report in the Local Governance Support Program to the public service asserting that a number of performance accountability instruments such as the Government Agency Performance Report (LKIP / LAKIP) are made unilaterally. Furthermore, they tend to appear to be a mere formality and not reliable in assessing the performance of public organizations.

Public organizations themselves constitute all state institutions at both central and regional levels of government whose financing comes from public funds, including regional apparatus at regional government level. Such regional apparatus serves as work units (SKPD). Each SKPD receives funding from the central and regional governments that are accommodated through the Local Government Budget (APBD). SKPD manages the fund with the concept of decentralization entailing work units (sub SKPD) below it. The funds granted to SKPD are provided by the government, consequently leading each SKPD to spend and report it accountably, transparently, effectively and efficiently.

Probolinggo City Government as one of the local governments in East Java province consists of 40 SKPD residing in its area. The issuance of Law No. 23 Year 2014 on Regional Government which is then followed up by the issuance of Government Regulation No. 18 Year 2016 on Local Government Agencies requires Probolinggo Government to change its institutional status in accordance with the Organizational Structure of Working Procedure (SOTK). The preparation of APBD of Fiscal Year 2017 is based on the new institutional change of SOTK which in its preparation employs performance-based budgeting analysis and money follows function pertaining to in its stipulation.

To prepare the annual budget well, the local government requires an information system that can serve as a tool in preparing performance-based budget. Such an information system for performance-based budgeting must be prepared based on Government Regulation 
No. 58 Year 2005 on Regional Financial Management and regulations pertaining to its implementation stipulated in the Minister of Home Affairs Regulations (Permendagri) No.13 Year 2006 on Guidelines for Regional Financial Management. It is also in accordance with the Amendment of the regulation, most recently referring to Permendagri No. 21 Year 2011 on the Second Amendment to Permendagri No. 13 Year 2006 on Guidelines for Regional Financial Management.

Planning, Budgeting and Reporting Information System (SIMRAL) is a computer application program particularly aimed at assisting local governments in the integrated planning and management of regional finances entailing planning, budgeting, and financial reporting of its area. Such a system can be carried out by the local governments to support the accrual accounting system. Accordingly, the output of this application is outlined as follows: 1). Planning: Forum for Planning and Development (Musrenbang), Regional Development Work Plans (RKPD), Work Plans of SKPD and Interim Budget Priorities and Funding Ceilings (PPAS); 2). Budgeting: Work Plans and Budgets (RKA), Budget Implementation Document (DPA), APBD and its amendments, and Provision of Funds Letter (SPD); 2). b Administration: Payment Letter (SPP), Warrant Payment Letter (SPM), Funds Disbursement Order (SP2D), Certificate of Deposit (STS), administrative registers, and other forms of controlling administration; 3) Reporting: Journal, Ledger, Subsidiary, all components of Accrual Based Financial Statements except Notes to Financial Statements (CaLK), and Accountability Report of Government Agency Performance (LkjIP/LAKIP).

This research attempts to particularly investigate the process of performance-based budgeting. Therefore, it only discusses the budgeting domain, as a part of SIMRAL. This research will not touch others aspects of SIMRAL having been previously mentioned. Accordingly, the discussion section adjusts to the purpose of this research.

In brief, the concept of SIMRAL model consists of 3 main parts, namely, 1) planning activities and budget, 2) implementing the planned activities and budget, and 3) conducting performance measurement. In accordance with the objectives of the research, which is to comprehend the meaning of performance-based budgeting process with the use of SIMRAL in Probolinggo, some of the concepts in the stage of planning activities and budget are to construe PPAS as input to produce APBD as output.

Theoretically, SIMRAL can be defined as a computer-based system that provides information to different groups of users with different authorities but similar needs. These users are incorporated into a formal organizational entity, for example, an agency of Regional Government Institutions that can encompass departments, sections, and even the smallest 
units in the institution. SIMRAL comprises a collection of important information closely related to people, places and all things that are present within or outside the local government organization's environment. Moreover, it follows that information is the result of processing data into a more beneficial and meaningful form to the receivers and can be used as a basis for decision making (Wahyono, 2004). Furthermore, Wahyono (2004) states that data are primary materials to create information, entailing a collection of symbols that represent facts, events, actions, objects, and so forth. Data, as 'raw materials', cannot be immediately used in decision making, but they have to be processed first so that it can be meaningfully understood and employed in decision making.

The utilization of SIMRAL in performance-based budgeting has never been investigated. Moreover, SIMRAL related manual has never been composed so that this research can be regarded as a preliminary study examining how SIMRAL is used in performance-based budgeting. SIMRAL itself has only been recently employed in 7 municipalities or regencies, and is a new information system combining stages of planning, budgeting and reporting into an integrated information system. In Probolinggo, the local government only started to utilize SIMRAL in 2015. However, with regard to the planning stage, it has not been fully accommodated. They have just started to implement it in planning and proposing the budget for the period of 2017.

This research is conducted by considering three things as follows: 1) concerning many findings of previous studies highlighting the mismatch between performance-based planning and budgeting, those studies have not considered an essential factor in investigating performance-based budgeting in local governments in Indonesia, which is an integrated information system for planning and budgeting (Widyantoro (2009); Setiyani (2011); Herawati (2012); Puspitasari (2013); and Slow (2014)); 2) SIMRAL as an integrated information system for planning, budgeting and reporting has never been previously examined. The researcher had confirmed this situation to the SIMRAL developer, BPPT; 3) many studies on performance-based budgeting were conducted in the era of the enactment of Law No. 32 of 2004 and its Amendment, but studies pertaining to the enactment of Law No. 23 of 2014 as the Amendment of Law No. 23 of 2014 on Regional Government have not been extensively conducted.

This study was conducted in the local government of Probolinggo considering that it is one of three local governments in East Java which has implemented integrated information planning and budgeting system (Dinas Komunikasi Informatika Kota Probolinggo, 2016). Therefore, it is interesting to examine its impact in achieving performance goals. The 
government of Probolinggo is also a local government that undergoes institutional transformation and policy changes in the realm of its administrative and financial administration, as a result of changes in legislation and in the institutional sector as well as financial management accountability. Institutional changes and local financial management policies necessitate great accountability and responsibility and there will, certainly, be many obstacles and problems encountered, primarily in terms of performance accountability. This research is expected to provide useful input regarding the implementation of institutional and policy changes by utilizing integrated information system in administration and financial administration, particularly for the local government of Probolinggo and other local governments in Indonesia in the pursuit of applying better performance-based budgeting.

\section{LITERATURE REVIEW}

The notion of budgeting in public sector organizations is a complex process. The characteristics of public sector budgeting differ from those of the private sector. In the private sector, the budget is a part of a company's information kept secret to the public. On the contrary, in the public sector, the budget must be informed to the public to be evaluated, criticized and discussed to gain feedbacks (Rahayu, 2007). This is tremendously beneficial to the improvement of governmental agencies' performance.

The performance of government agencies has been the subject of much criticism in recent years, especially since the emergence of a more democratic climate in government. People always expect the implementation of good and fair public services. However, in practice the government cannot always meet such expectations, both at the center and regional levels. Until now, there are still many cases of public services that are far from public expectations (RTI International, 2009).

As a system, state budget planning has undergone many developments. The current state budget planning system has evolved and changed in accordance with the dynamics of public sector management and the emerging demands of the community, the budgeting system applying the New Public Management (NPM) approach. The emergence of NPM has a direct effect on the concept of state budget in general. One of the effects is the change of the budget system from the traditional budget model to a more performance-oriented model.

Performance is a picture of the achievement of the implementation of an activity, a program or a policy in attaining the goals, objectives, missions and visions of the organization (Bastian, 2006). Every organizational activity should be measured and expressed in relation to the vision and mission of the organization. The products and services will lose 
their value if the contribution of these products and services does not closely correspond to the achievement of the organization's vision and mission. The budget can be interpreted as a package of revenue and expenditure estimates that are expected to occur in one or more future periods.

Public sector budget is a periodic activity and financial plan (usually in the annual period) containing the programs and activities and the amount of funds earned (income) and required (expenditure) in order to achieve the objectives of the public organization. According to the Govermental Accounting Standards Board (GASB) (in Bastian, 2006), the budget is defined as a financial operation plan, which includes estimates of proposed expenditures, and the expected source of income to finance it within a given period of time. Budgeting, furthermore, is an activity to allocate limited financial resources to finance organizational expenditures that tend to be unlimited (Haryanto, Sahmuddin, \& Arifuddin, 2007).

Budgeting is a financial plan that systematically shows the allocation of human resources, materials, and other resources. Various types of government budgeting systems have been developed to serve a variety of purposes, some of which serve as financial control, management plans, a determinant of priorities for spending the budget and public accountability. Performance-based budgeting, therefore, is an option for use as a government performance measurement and accountability tool.

Performance-based budgeting is a method of budgeting for management to link any funding realized in all activities performed with expected outputs and outcomes, including a matter of efficiency in attaining such aspects. These outputs and outcomes are outlined in performance targets for each work unit. Regarding how the goal is achieved, it is materialized in the programs followed by financing each level to achieve the goals. Thus, performancebased budgeting is a system oriented to the organization's outputs and is closely related to the organization's vision, mission and strategic plan.

The main characteristic of performance-based budgeting is that the budget is prepared by considering the linkage between the funding (input) and the expected outcomes; accordingly, it is to provide information on the effectiveness and efficiency of the activities (Haryanto, Sahmuddin, \& Arifuddin, 2007). Performance-based budgeting system has currently grown rapidly and been widely used by developing countries in the world as a substitute for the old budgeting system known as line item budgeting system (Bastian, 2006). In the line item budgeting system, the main emphasis is on input resulting in an increased 
amount of budget compared to those of the previous years. Moreover, it places a less emphasis on the output to be achieved and less consideration of nationally stipulated priorities and policies.

In the Attachment Regarding Regulation of the Minister of Finance of RI No. 102 Year 2008 on the Guidelines for Formulation and Review of RKA-KL Year 2009, the implementation of effective performance-based budgeting requires preconditions as follows:

a) A supportive environment or condition supporting and oriented to the achievement of performance has been established.

b) An effective control system requires managerial accountability.

c) There has been a reliable system and accounting methods practiced before the introduction of an integrated financial management system.

d) An output-oriented mechanism of resources allocation has been established.

e) An effective financial audit system has been implemented before a performance audit is administered.

According to the Formulation of Performance-Based Budgeting Manual (Supervisory Deputy of Regional Financial Implementation Division, Supervisory Directorate of Regional Finance 3 BPKP, 2008), the conditions that must be prepared as a trigger for successful implementation of performance-based budgeting are as follows:

a) Leadership and commitment of all organizational components.

b) Ongoing administrative refinements.

c) Sufficient resources for attempting at such refinements (money, time and people).

d) Clear rewards and punishments.

e) A strong determination to succeed.

Moreover, Schick (2004) asserts that there are several things that must be considered and fulfilled before giving full authority to the budget users. The concept of performancebased budgeting cannot be applied simultaneously if it is not able to meet the preconditions. This precondition is a prerequisite for comprehensive reform of state expenditure. These conditions are spelled out as follows:

a) Before performance-based budgeting is implemented, it is best to create a supportive, performance-oriented environment or condition.

b) Before making any changes to the control of outputw, a strong control system of inputs should have been established.

c) Before changing the accounting system into an accrual system, it is better to have a good account for cash system running. 
d) Before changing the control mechanism to an internal control system which is a major requirement for shifting into a managerial accountability mechanism, a good external control system should have been established.

e) A reliable accounting system should have run well prior to the implementation of an integrated financial system.

f) An output-oriented allocation mechanism should have been established prior to focusing on outcomes.

g) A contract mechanism to the market should have run well prior to the implementation of performance contract mechanisms.

h) An effective financial audit system should have been in place before a performance audit is practiced.

i) A realistic and predictable state budget should have been in place before demanding managers to act efficiently and effectively in using their budgets.

\section{METHODS}

This research employed an interpretive paradigm approach. This paradigm is used in research with the aim to provide interpretation and to understand the object to be studied. The quality of the theory in this paradigm is measured from its ability to interpret (Triyuwono, 2009). The interpretive paradigm makes use of a nominalist point of view that sees social reality as a label, a name or a concept used in constructing reality. Accordingly, such a reality is not a real thing, but merely the act of naming of objects created by humans or simply the products of the humans themselves. In an interpretive approach, not only does the researcher strip the surface, but he explores the deepest part of reality itself through interpretation or comprehension.

Interpretive research is regarded as qualitative research because the data gathered are qualitative data. The focus of this research is phenomenology as one of the branches of interpretive paradigm research. Phenomenology is a view that emphasizes the subjective experience of humans and seeks to understand events and their relation to people in certain situations (Moleong, 2005). The flow of phenomenological research aims to reveal the meaning of human behavior in everyday life as a group, an individual, and a society.

Muhadjir (2000) mentions Geertz's (1973) view that interpretive aims to seek meaning by trying to understand a phenomenon, not constructing laws. One method employed in the interpretive paradigm is phenomenology, the understanding of which places an emphasis on the process of observing, collecting data, analyzing and making conclusions 
(Muhadjir, 2000). This qualitative approach in this study aims to describe the meaning of the phenomenon observed, that is the performance-based budgeting process utilizing SIMRAL in Probolinggo. To carry out the study, it considers the values, norms, cultures, organizational structures and other driving factors in the process of organizing the performance-based budgeting with the SIMRAL utilization in Probolinggo.

Phenomenology was employed in this study because it conceptually has become a philosophical foundation, a research method and a perspective pervading all types of qualitative research. Another consideration is that the process of preparing budget can be regarded as a social phenomenon involving interactions between various parties. The phenomenological approach touches the curve of a double reality, for it presents the relationship between the researcher and the informants directly. Moreover, it is able to better explain the phenomena that occur as well as the patterns of values encountered.

The type of phenomenological research method used in this study is transcendental phenomenology, as expressed by Husserl that positive science requires a companion approach to phenomenological philosophy (Kuswarno, 2009). This method invites us to return to the real source or reality, to place these objects ( $z$ den sachen selbst), observed objects to 'speak' through the phenomenological description in search of the essence of signs (wessenchau).

In this domain, the researcher's task is, first, to make a descriptive observation related to the consciousness phenomenon between the objective and the subjective or the consciousness, such as in the form of awareness of what is seen in relation to the description of the myth of the organization, its cultures, and symbols. Secondly, in this study tribal language phenomenology was done entailing awareness (intentionality), process (epoche), idea or form (eidos), essence (eidic reduction), perceived object (noema), subjective comprehension (noesis), and pure intuition in which reason is kept out (apodictic). From that explanation, we can conclude that phenomenology is a combination of events and consciousness. Moreover, phenomenology employs a subjective reflection and intuition as the main tools to respond to the results of the subject's intensive analysis. It involves epoche and process of understanding (extension) by paying more attention to the meaning of subjectively interpreted things beyond what is seen. Accordingly, the researcher conducted this study by deciding who will be investigated, the limitations, the data collection and the analysis of the phenomenological data.

To proceed with the next stage, the researcher identified the important themes of what the informants experienced, particularly referring to the Regional Government Budget 
Team (TAPD) of Probolinggo in the process of drafting the performance-based budget using SIMRAL. The next step was to analyze the data through the development of correlation between noema and noesis, commonly referred to as a noetic or noumatic correlation investigating the performance-based budgeting process with the SIMRAL utilization in the regional government of Probolinggo considering a given situation, a condition and a context gained from the subjective reflection of the researcher. The final step involved the process of abstraction pertaining to the essence of correlation between noema and noesis in order to convey the meaning of the overall essence of the informants' experience.

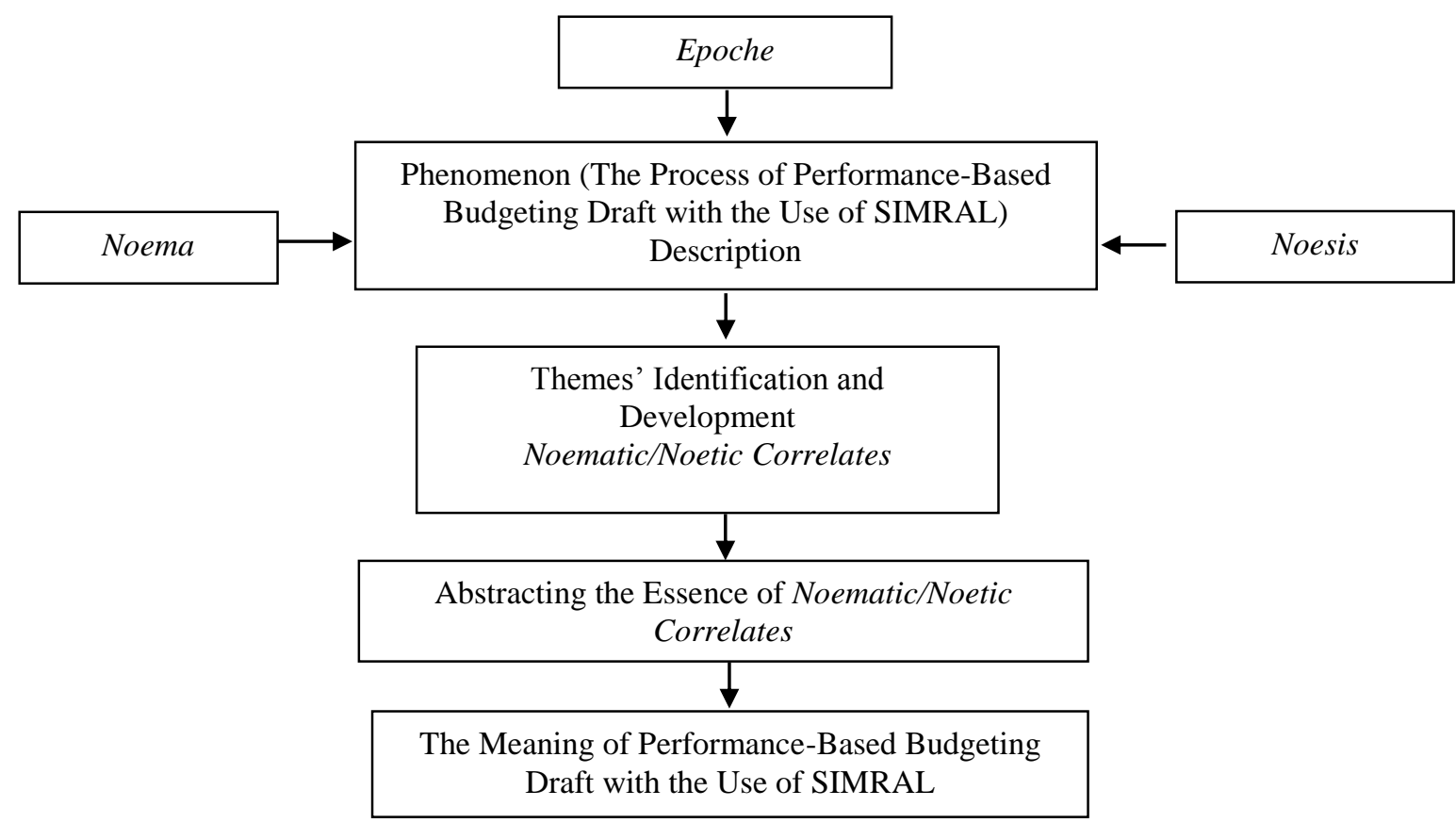

Source: Sanders (1982, hlm: 357)

Figure 1: Data Analysis Technique

Not only did the present study describe the phenomenon, it also aimed to elucidate the described phenomenon and the deep structures of it. Such practical concepts were then analyzed by comparing the findings or understanding of the empirical reality of the organization with the concept of performance-based budgeting as well as other related concepts. Through such a method, it is expected that researcher can arrive at the purpose of the study, which is to understand the process of the performance-based budgeting in the government of Probolinggo. 


\section{RESULT}

\section{Performance-Based Budgeting}

The budgeting process in the public sector possesses a quite unique characteristic, for it differs from those of budgeting in the private sector. Unlike the private sector that tends to conceal its budget from the public as one of the company's strategies and strengths, the public sector budget is required to be informed to the public in order to be evaluated and discussed so that feedbacks or criticisms can arise (Rahayu, Ludigdo, \& Affandy, 2007). This is intended to provide input to improving the quality of the budget in the public sector.

The performance of governmental agencies has been heavily criticized in the reformation era due to the development of a more democratic government. The public always expects that the government can equitably provide proper public services and yield products and services of good quality. In practice, however, such expectations are hardly fulfilled by the government, both at the central and regional levels. Various cases in which the public services are counterproductive appear to be prevalent (RTI International, 2009).

The results of interviews, documentation and observation were organized, categorized and coded on the basis of the research questions. The next step was done by determining the noema based on the categorization and coding. To answer the research question "How does TAPD of Probolinggo interpret the process of performance-based budgeting by employing SIMRAL in APBD of Probolinggo?", the researcher found 6 noema, namely, 1) the understanding of performance-based budgeting, 2) the performance planning, 3) the budget spending, 4) the performance measurement, 5) the performance evaluation and 6) the performance reporting. The results of the data analysis are shown in Table 1.

Table 1 : Data Analysis Concerning the First Research Question Based on the Understanding of Performance-Based Budgeting

Triangulation

Noema

Information Gained from the Interviews Data

\begin{tabular}{|c|c|c|}
\hline Information Gained from the Interviews & Data & \\
\hline The output of the activities is clear & \multirow[t]{5}{*}{ Observation } & \multirow{5}{*}{$\begin{array}{c}\text { Output and } \\
\text { outcome }\end{array}$} \\
\hline The spending of the budget corresponds with its effectiveness & & \\
\hline The activities have output, supporting data, targets & & \\
\hline Activities-oriented programs & & \\
\hline Budget plans with clear objectives and & & \\
\hline The budget is not performance-based yet & \multirow[t]{3}{*}{ Renja } & \multirow[t]{4}{*}{ Work Plan } \\
\hline Make work plans first and connect them to RKPD & & \\
\hline Arrange the activities first and connect them to Renstra & & \\
\hline The plan is not evaluated in RKPD & DPA SKPD & \\
\hline
\end{tabular}




\begin{tabular}{|c|c|c|}
\hline Pagu is not clear & & \\
\hline Stipulate the income and expenditure & & \\
\hline SPM and SOP have not been stipulated & \multirow{3}{*}{$\begin{array}{l}\text { RKA SKPD } \\
\text { DPA SKPD }\end{array}$} & \multirow{3}{*}{$\begin{array}{c}\text { Budget } \\
\text { Implementation }\end{array}$} \\
\hline The implementation deviates from the plan & & \\
\hline The implementation diverts, financial process gets difficult & & \\
\hline The performance of each activity is not detected & \multirow{2}{*}{$\begin{array}{l}\text { LAKIP } \\
\text { DPA SKPD }\end{array}$} & \multirow{2}{*}{$\begin{array}{l}\text { Performance } \\
\text { Measurement }\end{array}$} \\
\hline $\begin{array}{l}\text { Many funds are spent for activities diverting from their planned } \\
\text { output }\end{array}$ & & \\
\hline Weak control and evaluation & LAKIP & \multirow{3}{*}{$\begin{array}{l}\text { Performance } \\
\text { Evaluation }\end{array}$} \\
\hline Work plans attainment in renstra is not clear & \multirow[t]{2}{*}{ DPA SKPD } & \\
\hline The role of the inspectorate has not effectively run & & \\
\hline The performance report is not well made & LAKIP & $\begin{array}{l}\text { Performance } \\
\text { Report }\end{array}$ \\
\hline
\end{tabular}

To answer the second research question "What are the constraints and problems faced in the process of implementing performance-based budgeting by using SIMRAL in the APBD of Probolinggo?", the researcher found 4 noema: communication, integrated application system, reward and punishment, and work ethic. The discussion on the results of the data analysis is presented in Table 2.

Table 2 : Data Analysis Concerning the Second Research Question Based on the Understanding of Performance-Based Budgeting

\begin{tabular}{|c|c|c|}
\hline Triangulation & & Noema \\
\hline Information conveyed from the results of the interviews & \multicolumn{2}{|l|}{ Data } \\
\hline More socialization should be done & \multirow[t]{5}{*}{ Observation } & \multirow{5}{*}{$\underset{n}{\text { Communicatio }}$} \\
\hline The standard has not been fully understood, need training & & \\
\hline Socialization is hardly done & & \\
\hline The chief should give instructions and monitor them & & \\
\hline The instruction is still not sound and clear & & \\
\hline The contraints involve the sytems and human resources & \multirow[t]{3}{*}{ Observation } & \multirow{3}{*}{$\begin{array}{l}\text { An integrated } \\
\text { application } \\
\text { system }\end{array}$} \\
\hline $\begin{array}{l}\text { A good accounting system is needed to link the plan and the } \\
\text { report }\end{array}$ & & \\
\hline The constraints are the system and human resources & & \\
\hline No reward & \multirow[t]{4}{*}{ Observation } & \multirow{4}{*}{$\begin{array}{l}\text { Reward and } \\
\text { punishment }\end{array}$} \\
\hline No clear punishment & & \\
\hline Reward and punishment are present only for individuals & & \\
\hline No reward and punishment & & \\
\hline The work ethic is not clear & Observation & Work ethic \\
\hline
\end{tabular}


Referring to 10 descriptions of the phenomena concerning performance-based budgeting above, identification of their meaning is presented in Table 3 to provide a better understanding of them.

Table 3 : Identification of Meaning of Performance-Based Budgeting by Employing SIMRAL

\begin{tabular}{lll}
\hline \multicolumn{1}{c}{ Noema } & & \multicolumn{1}{c}{ Noesis } \\
\hline 1. Output and outcome & 1. & Work results \\
2. Work Plans & 2. Budgeting is reffered by the planning (reversed) \\
3. Budget Implementation & 3. SOP and SOM are not available \\
4. Performance Measurement & 4. Peformance = budget spent \\
5. Peformance Evaluation & 5. The parameter for performance is not clear yet \\
6. Peformance Report & 6. Evaluation for the efficiency and effectiveness of the \\
& & activities does not exist \\
1. Communication & 1. The procedure does not exist \\
2. An integrated and computerized & 2. Separated application \\
3. Reward and punishment & 3. Reward and punishment for wok attainment are not \\
4. Work ethic & 4. Document attainment
\end{tabular}

\section{Identification of Themes \& Development} Noematic/Noetic Correlates

1. The performace-based budgeting is not based on the plan

2. Performance report is still in the form of document completeness

3. The performance of Budgeting staff is not at their optimum performance

4. The leaders hardly motivate and direct their workers

5. SIMDA vS SIMRAL

\section{Abstraction of the essence of \\ Noematic/Noetic Correlates}

1. The discrepancy between the plan and the budget

2. The performance report has not run well yet

3. The human resources need strengthening

4. The role of the leader is not significant

5. SIMRAL as an integrated system

\section{The disobedience of budgeting to planning}

\section{Meaning}

With regard to such above notion, it is apparent that all informants opted for this research yielded similar responses. By understanding their responses, it can be construed that the discrepancy between the planning and the budgeting resulted in unfavorable performance reporting. From the analysis of the interviews and related documents, the researcher found that factors causing such a discrepancy involve the lack of good human resources, the lack of SKPD leadership and the previous information system that has not fully integrated the planning and budgeting process.

With regard to three factors mentioned above, the one pertaining to the information system has been handled by Probolinggo government by employing SIMRAL since 2016. SIMRAL, which is an integrated application covering planning and reporting, can facilitate 
the preparation of Probolinggo City APBD for Fiscal Year 2017 by synchronizing planning documents (PPAS) and budgeting documents (RKA). By doing so, it is expected that the execution and reporting of the performance-based budgeting in 2017 can run optimally in accordance with all elements set out in the planning documents.

With regard to the enactment of Government Regulation Number 18 Year 2016 concerning the Regional Agencies followed up by Probolinggo Municipal Government Regulation Number 7 Year 2016 concerning Establishment and Composition of Regional Agencies and Probolinggo Mayor Regulation on Description of Duties of SKPD Year 2017, it fully provides an ideal condition to measure the municipal government's performance. Moreover, with the employment of SIMRAL by Probolinggo government for the first time, to what extent the government has attained its objectives or targets since the beginning of 2017 can be systematically measured. Such a novel system is expected to successfully serve as a parameter to measure how serious it is the Probolinggo government pertaining to its efforts to improve its performance accountability.

\section{Utilization of Planning, Budgeting and Reporting Information System (SIMRAL)}

The use of SIMRAL by Probolinggo government as an integrated application system provides input and output generated by managers who refer to those managing the budget and providing information that will be used by stakeholders. Revi (2013) further states that Management Information System has some purposes as follows: providing information necessary to calculate the cost of services, products and other objectives that the management desires; providing information used in planning, controlling, evaluating, and continuous improvement and providing information for decision making.

In the discussion section, the utilization of the SIMRAL refers to the employment of SIMRAL module thoroughly ranging from planning to reporting process. The use of SIMRAL referring to an application of planning process in 2016 was not discussed in this study because it did not cover the performance-based budget planning process which becomes the focus of this research.

To answer the research question "How is the understanding of the employee pertaining to the process of performance-based budgeting by using SIMRAL in Probolinggo City APBD?", the researcher found 6 noema: the understanding of the meaning of PerformanceBased Budgeting, performance planning, budget implementation, performance measurement, performance evaluation and performance reporting. The results of data analysis are shown in Table 4. 
Table 4 : Data Analysis Concerning the First Research Question Based on the Undertanding of SIMRAL's Utilization

\begin{tabular}{|c|c|c|}
\hline \multicolumn{2}{|l|}{ Triangulation } & \multirow[t]{2}{*}{ Noema } \\
\hline Information Gained from the Interviews & Data & \\
\hline The need of to have an integrated application system & \multirow[t]{2}{*}{ Observation } & \multirow{2}{*}{$\begin{array}{l}\text { Targets and } \\
\text { objectives of } \\
\text { SIMRAL's } \\
\text { Utilization }\end{array}$} \\
\hline To ease the planning and budgeting control & & \\
\hline Fitures of application system & \multirow{3}{*}{$\begin{array}{l}\text { Observation } \\
\text { Module } \\
\text { SIMRAL }\end{array}$} & \multirow{3}{*}{$\begin{array}{l}\text { The Utilization } \\
\text { Level of SIMRAL }\end{array}$} \\
\hline The authority of the application system's users & & \\
\hline The administrators have several fuctions & & \\
\hline The need to have computers of good quality & \multirow{2}{*}{$\begin{array}{l}\text { Observation } \\
\text { Module } \\
\text { SIMRAL }\end{array}$} & \multirow{2}{*}{$\begin{array}{c}\text { The Availability of } \\
\text { Facilities for } \\
\text { SIMRAL }\end{array}$} \\
\hline Internet connection & & \\
\hline The stage of preparing performance-based budgeting & \multirow{3}{*}{$\begin{array}{c}\text { Observation } \\
\text { Module } \\
\text { SIMRAL }\end{array}$} & \multirow{3}{*}{$\begin{array}{l}\text { The Process in } \\
\text { SIMRAL }\end{array}$} \\
\hline The stage of performance-based budgeting & & \\
\hline Executive dashboard & & \\
\hline
\end{tabular}

To answer the second research question "What are the constraints and problems faced in the process of preparing the performance-based budgeting by using SIMRAL in Probolinggo City APBD?", the researcher found 2 noema, namely quality and quantity which entail human resources involved in peforming SIMRAL and programs intended for the employee development concerning their understanding of SIMRAL. The results of the data analysis are shown in Table 5.3.

Table 5 : Data Analysis Concerning the Second Research Question Based on the Understanding of SIMRAL's Utilization

\begin{tabular}{|c|c|c|}
\hline \multicolumn{2}{|l|}{ Triangulation } & \multirow[t]{2}{*}{ Noema } \\
\hline Information Gained from the Interviews & Data & \\
\hline $\begin{array}{l}\text { Good human resources (SDM) ntaking part in training programs } \\
\text { tailored to their field of work as planning, budgeting, } \\
\text { administration, accounting and report. }\end{array}$ & \multirow[t]{3}{*}{ Observation } & \multirow{3}{*}{$\begin{array}{l}\text { Quality and } \\
\text { Quantity of the } \\
\text { SDM needed to } \\
\text { apply SIMRAL }\end{array}$} \\
\hline New SKPD are present & & \\
\hline Lack of SDM understanding SIMRAL in some SKPD & & \\
\hline $\begin{array}{l}\text { Lack of training programs specially tailored to SIMRAL } \\
\text { understanding }\end{array}$ & \multirow[t]{2}{*}{ Observation } & \multirow{2}{*}{$\begin{array}{l}\text { Training Programs } \\
\text { for the staff } \\
\text { development in } \\
\text { using SIMRAL }\end{array}$} \\
\hline $\begin{array}{l}\text { The improvement of the SDM quality through training programs } \\
\text { and group discussion }\end{array}$ & & \\
\hline
\end{tabular}

Based on the 6 descriptions of the phenomenon above, identification of their meaning is provided in Table 6.

Table 6 : Identification of Meaning of Performance-Based Budgeting by Employing SIMRAL 
1. Targets and objectives of using SIMRAL

2. The utilization level of SIMRAL

3. The availability of facilities for SIMRAL

4. Process needed in SIMRAL

1. Quantity and Quality of SDM to apply SIMRAL

2. Training programs for the staff development in making use of SIMRAL

\section{Noesis}

1. SIMRAL corresponds with its objectives

2. SIMRAL is a tool for sharing and transparency of information

3. SIMRAL depends on good internet connection

4. SIMRAL is good as it has executive dashboard

1. SDM is not equally distributed, not one-man show

2. SIMRAL needs discussion, training programs and coordination

\section{Identification of Themes \& Development} Noematic/Noetic Correlates

1. SIMRAL accommodates the need to have consistent planning and budgeting system

2. Qualified SDM serve as an important factor

\section{Abstraction of the essence of}

Noematic/Noetic Correlates

1. SIMRAL is the connector between the planning and budgeting

2. SDM of good quality

\section{SIMRAL is a solution to the disobedience of budgeting to planning}

Based on the identification above, it can be seen that the use of SIMRAL is meant as a tool that can synchronize the planning and budgeting documents as long as it is supported by qualified human resources to meet all elements that it requires. The results of the interviews led to such interpretation of meaning in which the notion mentioned above is considered as key factors in the successful utilization of SIMRAL in performance-based budgeting.

The statement which reads "SIMRAL can only be beneficial if it meets the requirements" refers to the clear division of authority, the availability of adequate facilities and internet connection, and the need to understand the features available in SIMRAL. If one or all of these conditions cannot be fulfilled, it will certainly preclude the efforts made to achieve the objectives of the SIMRAL's utilization in performance-based budgeting. In other words, those three prerequisites are closely interrelated.

\section{DISCUSSIONS}

The performance-based budgeting analysis on Probolinggo Municipal Government indicates that the local government needs to do a revamp on the planning and budgeting stage. This is so, for the implementation of performance-based budgeting in Probolinggo only revolves around formatting and technical changes. Moreover, it is supported by the fact that 
they still use the old budgetting system, the general indicators of which are still unreliable and insufficient in accordance with the performance plans documents.

The use of traditional approach in performance-based budgeting practices in Probolinggo is still found to be frequent, the performance indicators (input, output and outcomes) of which do not provide clear standard of size and cost. Moreover, the local government performance reports tend to appear to be a mere formality and are not reliable to assess the work units or the SKPD's performance.

The results revealed that the process of finding meaning in terms of the understanding of the meaning of performance-based budgeting indicates that the problem of synchronization betweenperformance-based planning and budgeting is the main meaning causing unfavorable performance reporting. This is exacerbated by the presence of unfavorable human resource, the lack of active leadership, and unplanned performance reporting.

Thus, it can be concluded that the implementation of performance-based budgeting in Probolinggo government is still of low quality. This conclusion is accentuated by the assessment of Probolinggo's Government Institution Performance Report (LAKIP) administered by the Ministry of Administrative Reform and Bureaucratic Reform (Kemenpan-RB) resulting in $\mathrm{C}$ rank (which is ranked 5th from 6 levels of the government performance accountability evaluation (AKIP).

Responding to such a situation, Probolinggo government, hence, needs to reform their bureaucracy and improve their system regularly. Those efforts can be started with utilizing SIMRAL as their information system to yield a reliable report that closely links their planning and budgeting with performance-based approach. Moreover, SIMRAL as an integrated application is deemed to be able to overcome a key problem pertaining to the inconsistency of performance-based planning and budgeting. It was confirmed by data gained from the informants stating that the planning and budgeting of Probolinggo APBD for Fiscal Year 2017 has been synchronized, as evidenced by all activities proposed in PPAS corresponding with those in RKA SKPD documents.

Kumorotomo \& Margono (1994) assert that the management information system is projected to implement data processing that will be utilized by an organization. In a similar vein, McLeod \& Schell (2008) argue that the management information system (MIS) is a computer-based system that provides information to users who have the same needs. Moreover, elements that represent a general management information system consist of input, data processing, and output (Kumorotomo \& Margono, 1994). 
Dipayana (2016) defines SIMRAL as a web-based planning, administration and reporting information system that can be accessed through browsers from various electronic devices (Windows PC/Laptop, Macbook, tablet and HP (Android / iPhone etc)). Furthermore, Diskominfo (2016) discloses that there are 3 scopes of SIMRAL application; 1) people, 2) technology, and 3) process. Each scope is interrelated so that SIMRAL can run in accordance with the purpose of its implementation.

SIMRAL comprises three main parts; they are planning, budgeting and reporting that will be distributed to each SKPD with integrated database system. Therefore, its output can be used by local leaders and SKPD leaders to assist them in making decision. On the other hand, the legislature can use it to monitore the performance of local government (Diskominfo, 2016). The utilization of SIMRAL is one of the efforts of Probolinggo Government in fulfilling the needs of integrated information quickly, accurately and completely, for it plays a role to support the administrative process of government, to maintain the public service, and to facilitate public dialogue and participation in making policy.

The results of this study reveal that the effectiveness of the new SIMRAL utilization can only function as its intended purposes if the requirements are fulfilled by the support of qualified human resources. "Terms and conditions" in the utilization of SIMRAL in the performance-based budget planning process are the interpretation presented by the informants. In another word, the usefulness of this integrated application system still requires management intervention in achieving the effectiveness of its utilization. Three prerequisites directly related to SIMRAL and qualified human resources indicate that SIMRAL is merely a tool in achieving performance in performance-based budgeting, not as a dominating factor in the improvement of performance quality in particular.

The researchers consider the necessity for reviewing the effectiveness of SIMRAL as an integrated budgeting system by looking at report of the level of achievement of performance. However, this does not put aside the fact that SIMRAL succeeds in maintaining the consistency of planning and budgeting performance on the preparation of APBD of Probolinggo City in Fiscal Year 2017.

Based on the synthesis of ideas elucidated above, the performance-based budget planning with the utilization of SIMRAL in Probolinggo City is interpreted as follows:

1. The disobedience of budgeting to planning;

2. SIMRAL is a solution to overcome such disobedience. 
Based on the results of the research, the informant's interpretation of the performancebased planning in the public sector has not been aligned with those stipulated in Government Regulations used as a reference to implement planning, budgeting and performance-based reporting in the public sector.

The performance-based budgeting jargon that technically has started to be applied since the enactment of Permendagri Number 13 Year 2006 on Guidelines for Regional Financial Management has not yet been aligned with the interpretation obtained from this research. There is still a discrepancy between performance-based planning and budgeting which results in unfavorable performance reporting. Such a discrepancy is caused by the unfavorable human resources, the lack of leadership qualities and separated system of planning and performance reporting.

On the other hand, the results of this phenomenological research reveal that SIMRAL utilization, even in such a very short time has been able to harmonize both planning and budgeting. The informant asserted that SIMRAL's utilization is very helpful, for it provides good technical process, and executive dashboard feature serving as executive control and supervisory function so that budgeting is arranged properly in accordance with prior planning.

The conclusion of the meaning that emerged from this research is the problem-solution interpretation given by the informants in which the meaning of performance-based budgeting is interpreted as something not yet ideal. However, on the other hand, they assumed that there is an initial solution to the problem, which is the presence of SIMRAL. This tendency is caused by a common interpretation saying that the implementation of appropriate rules will not be attained if they are not 'forced' through the implementation of an integrated system. This actually has not yet demonstrated a meaningful interpretation when it is compared to performance-related rules implying that performance conformity should be measured from the start of the plan, which is achieving targets according to the five year annual targets stipulated in RPJMD.

The researchers argue that the interpretation of performance-based budgeting with SIMRAL utilization in Probolinggo has not fully described the measurement of performancebased planning in Fiscal Year 2017. Consistency of budget planning should not be seen only from how the output planning document coresponds with the budgeting document.

The consistency of planning with new budgeting can be more obviously seen when LAKIP as a reporting document has been audited. Such a situation can technically and 
accurately show whether the meaning conveyed in this study has really represented the consistency of planning and also performance-based reporting with SIMRAL utilization.

TAPD Kota Probolinggo can establish a viable change by refining available steps in accordance with the problems and obstacles conveyed by the informants. The followings are some recommendations for Probolinggo Government: Improving the quality of performancebased budgeting by maintaining the consistency of planning and budgeting not only in the final planning documents and initial budgeting documents, but also in the RPJMD at the Regional level and Strategic Plan (Renstra) at the SKPD level. Then, it should be followed up by reviewing the planning stages until the final drafting of PPAS is stipulated as the basis for the formulation of the initial budgeting document (RKA); Improving the quality of human resources by providing more training programs and implementing activities intended to strengthen the understanding of SIMRAL so that it can maximize the potential SIMRAL's features in accordance with the expected goals.

Based on the results of the analysis conducted by the researchers in the previous chapters, some conclusions can be drawn: TAPD iinterpreted Performance-Based Budgeting by utilizing SIMRAL as: the disobedience of budgeting to planning and solution to overcome such disobedience. Therefore, the conclusions can be synthesized as "SIMRAL is a solution of the disobedience of budgeting to planning."

The understanding of the meaning of Performance-Based Budgeting with the use of SIMRAL does not necessarily make Probolinggo City Government implement it in accordance with the rules and it is due to several reasons outlined as follows: a discrepancy between planning and budgeting, performance reporting which has not run well, the necessity for strengthening the human resources, SKPD's lack of leadership qualities, and the employment of an application system which has not been integrated like SIMRAL

\section{REFENRENCES}

Bastian, I. (2006). Akuntansi Sektor Publik: Suatu Pengantar. Jakarta: Erlangga.

Deputi Pengawasan Bidang Penyelenggaraan Keuangan Daerah Direktorat Pengawasan Penyelenggaraan Keuangan Daerah Wilayah 3 Badan Pengawasan Keuangan dan Pembangunan. (2008). Pedoman Penyusunan Anggaran Berbasis Kinerja.

Dinas Komunikasi dan Informatika Kota Probolinggo. (2016). Pengenalan Aplikasi SIMRAL (Sistem Informasi Perencanaan, Penganggaran dan Pelaporan). Materi Pengenalan SIMRAL di Kota Probolinggo. Probolinggo: DPPKA Kota Probolinggo.

Dipayana, M. A. (2016). SIMRAL: Identifikasi Permasalahan Implementasi Awal. Materi Pengenalan SIMRAL di Kota Probolinggo. Probolinggo: DPPKA Kota Probolinggo. 
Haryanto, Sahmuddin, \& Arifuddin. (2007). Akuntansi Sektor Publik. Semarang: Badan Penerbit Universitas Diponegoro

Kumorotomo, W., \& Margono, S. A. (1994). Sistem Informasi Manajemen: Dalam Organisasi-organisasi Publik. Yogyakarta: Gajah Mada University.

Kuswarno, E. (2009). Metode Penelitian Komunikasi - Fenomenologi: Konsepsi, Pedoman, dan Contoh Penelitiannya. Bandung: Widya Padjadjaran.

McLeod, R., \& Schell, G. P. (2008). Sistem Informasi Manajemen. Jakarta: Salemba Empat.

Moleong, L. J. (2005). Metodologi Penelitian Kualitatif. Bandung: Remaja Rosdakarya.

Muhadjir, N. (2000). Metodologi Penelitian Kualitatif Edisi IV. Yogyakarta: Rake Sarasin.

Rahayu, S., Ludigdo, U., \& Affandy, D. (2007). Studi Fenomenologis terhadap Proses Penyusunan Anggaran Daerah (Bukti Empiris dari Satu Satuan Kerja Perangkat Daerah di Propinsi Jambi). Makassar: Simposium Nasional Akuntansi X.

Revi, A. (2013). Efektivitas Penggunaan SIMAK-BMN dalam Peningkatan Kinerja Staf Pengelola Barang Milik Negara di Universitas Hasanuddin. Tesis, Fakultas Ekonomi, Universitas Patria Artha Makassar.

RTI International. (2009). Local Governance Support Program: Final Report. United States Agency for International Development (USAID)/Indonesia. Dipetik September 21, 2016, dari pdf.usaid.gov/pdf_docs/Pdacp359.pdf

Sanders, P. (1982). Phenomenology: A New Way of Viewing Organizational Research. Academy of Management Review, 7(3), 353-360.

Schick, A. (1994). From the Old Politics of Budgeting to the New. Public Budgeting \& Finance, 14(1), 135-144.

Triyuwono, I. (2009). Perspektif, Metodologi dan Teori Akuntansi Syariah. Jakarta: Raja Grafindo Persada.

Wahyono, T. (2004). Sistem Informasi. Yogyakarta: Graha Ilmu. 